\title{
Spatial Analysis of Worn-Out Urban Texture in Zanjan City with Emphasis on Livability Approach
}

\author{
KARAMAT ALLAH ZIYARI \\ Department of Geography and Urban Planning, University of Tehran, Tehran, Iran.
}

ALIREZA ANBARLOU

Futurology Department, Shakhes Pajouh Institute, Isfehan, Iran.

HEIDARI, MOHAMAD TAQI

Assistant Professor of Geography and Urban Planning, University of zanjan, Iran.

KAMRAN YEGANEGI

Futurology Department, Shakhes Pajouh Institute, Isfehan, Iran.

Email: yeganegi.k94@gmail.com

\begin{abstract}
Achieving life viability is considered as one of the strategic goals of sustainable urban development that human beings have been constantly seeking for its quantitative and qualitative promotion during their lifetime. Therefore, it can be said that viability is both a goal and a means of sustainable development. In this regard, the aim of the present paper is to evaluate and measure the viability indicators at the level of the worn-out texture of Zanjan city. To this end, descriptive-analytical method and field survey have been used. Samples were selected using simple random and for the purpose of the study, the sample size was 38. To analyze the collected data using SPSS software, one-sample T-test and independence spatial analysis (autocorrelation) (Moran analysis) were used. The findings show that the livability status in time-out texture of Zanjan city in terms of statistical population is desirable and acceptable. According to the results, the social index with the score $(t=29.655)$ has obtained the highest score. Moran analysis also suggests that the lack of livability concentration index unbalanced. the biomagulability index is not balanced. Translation error. In this regard, it can be said that the Debaghlar area with a coefficient of ( $Z$ score $=1.578629)$ has the highest rank. After that, the Yeri Balla with a coefficient of $(Z$ score $=1.41092)$ and Haghverdi with a coefficient of $(Z$ score $=1.301319)$ are placed in the next ranks.
\end{abstract}

Keywords: Independency Analysis, Worm-Out Texture, Livability, Zanjan City.

\section{Introduction}

Urban areas are regarded as the main centers of economic, social and political growth of each country. Thus, they prove themselves as the most attractive places to create wealth, job, creativity and innovation. Nevertheless, urban areas, nowadays, confront major challenges in the terms of physical and environmental destruction, social deprivation, insecurity, unemployment, housing shortage and traffic, which leads to decrease in the quality of life of citizens. However, policymakers and planners at the international and national levels continue to emphasize the capability of cities to improve people's lives (Rezvani et al., 2009; 88; Motaseli, 2013, 36). Thus, viability is a complex term associated with the condition and situation of population in a region that encompasses psychological dimensions and includes indicators such as 
satisfaction, happiness and security (Hosseini et al., 2012, 2; Seifodini, 2002, 375). According to the definitions offered, the concept of livability is a quality which iccludes not only the internal characteristics of the environment, but also the function associated with the behavior of the interaction between the environmental features and the individual characteristics (Pacione,1990,32). In this regard, the purpose of the present study is to measure development indicators in urban areas and districts, with emphasis on livability indicators in Zanjan city. Therefore, the present research seeks to answer the following question: what's the level of Zanjan city areas in terms of development indicators and quality of livability?

\section{Literature Review}

Discussion on the characteristics of a livable city dates back to 1958, when Landscape Architecture Journal published a short collection of professional planners and academic scholars on the creation of a livable city. Interestingly, none of the authors of the articles had used the terms "livable" or "livability" in their writings. Instead of addressing the current urban problems, the papers deal with the ugliness of modernism, the causes of city emancipation in favor of the countryside, and strategies to make urban centers more attractive. The National Organization of Arts first introduced the term "livability" in 1970 to attain their given urban planning ideas. Then, other research centers and organizations such as the Environmental Protection Agency conducting numerous studies on the most American livable cities has used the term. After that time, other centers and research organizations have used the term. Nowadays, with the growing problems of human societies and their increasing escalation and the decline in the quality of life and living standards of residents in different places it has been mainly used: so that most designers, planners and urban decision makers paid more attention to it. In the case of livable city, various studies have been carried out from a variety of perspectives abroad and inside the country, some of the most recent and relevant studies to the subject of the present research have been presented in the following table:

Summary of some internal and external studies conducted on livability

\begin{tabular}{|c|c|c|c|c|c|c|}
\hline Result & Place & Method & purpose & Title & Year & Researchel \\
\hline $\begin{array}{l}\text { Urban management, } \\
\text { historical pattern and } \\
\text { natural landscape are the } \\
\text { most important factors } \\
\text { affecting the city's } \\
\text { viability. In the Iranian } \\
\text { city, the compression of } \\
\text { the photo interface is } \\
\text { viable. }\end{array}$ & $\begin{array}{c}\text { areas } \\
22,15,1 \\
\text { Tehran }\end{array}$ & $\begin{array}{l}\text { Quantitative } \\
\text { and } \\
\text { qualitative }\end{array}$ & $\begin{array}{l}\text { Introduction } \\
\text { of key } \\
\text { factors } \\
\text { influencing } \\
\text { the sha } \\
\text { livability pe } \\
\text { of the city }\end{array}$ & $\begin{array}{c}\text { Formulating the } \\
\text { principles of the } \\
\text { spatial development } \\
\text { model and the shape } \\
\text { of the livability city of } \\
\text { Iran }\end{array}$ & 2014 & $\begin{array}{c}\text { Bandar } \\
\text { Abad }\end{array}$ \\
\hline $\begin{array}{l}\text { Conceptual model and } \\
\text { livability criteria are } \\
\text { identified in cities. }\end{array}$ & Iran & Quantitative & $\begin{array}{l}\text { Introducing } \\
\text { the Pattern } \\
\text { of the } \\
\text { livability } \\
\text { City of Iran }\end{array}$ & $\begin{array}{l}\text { Review of the global } \\
\text { and indigenous } \\
\text { standards of the } \\
\text { livable city }\end{array}$ & 2014 & $\begin{array}{c}\text { Majedi et } \\
\text { al }\end{array}$ \\
\hline $\begin{array}{l}\text { Identification of } \\
\text { contingency factors - } \\
\text { local (microstructure) - } \\
\text { have a greater share in } \\
\text { the production and } \\
\text { reproduction of the } \\
\text { existing tissue viability } \\
\text { in the transcontinental } \\
\text { (macro) structures. }\end{array}$ & Zanjan & $\begin{array}{l}\text { Quantitative } \\
\text { and } \\
\text { qualitative }\end{array}$ & $\begin{array}{l}\text { Provide } \\
\text { sustainable } \\
\text { viability } \\
\text { strategies in } \\
\text { urban areas }\end{array}$ & $\begin{array}{l}\text { Analysis of the } \\
\text { livability of worn-out } \\
\text { urban texture: Case } \\
\text { Study: Worn-out } \\
\text { extures in the Central } \\
\text { District of Zanjan city }\end{array}$ & 2016 & Heidari \\
\hline Many of the city's major & Australia & qualitative & Australian & Resilience and & 2014 & Newton \\
\hline
\end{tabular}




\begin{tabular}{|c|c|c|c|c|c|c|}
\hline $\begin{array}{l}\text { infrastructure has made } \\
\text { the city of Australia } \\
\text { more affordable, In other } \\
\text { words, it is not } \\
\text { sustainable. }\end{array}$ & & & $\begin{array}{c}\text { viability } \\
\text { Sustainabilit } \\
\text { y Survey }\end{array}$ & $\begin{array}{c}\text { Sustainability? } \\
\text { Technological-Social } \\
\text { Challenges-Cities of } \\
\text { the Twentieth Century }\end{array}$ & & \\
\hline $\begin{array}{l}11 \text { general areas related } \\
\text { to social well-being and } \\
\text { their relationship with } \\
\text { health and well-being } \\
\text { were approved, which } \\
\text { included crime and } \\
\text { security, education, } \\
\text { occupation and income, } \\
\text { health and social } \\
\text { services, housing, } \\
\text { recreation, local food } \\
\text { and the environment, } \\
\text { natural environment } \\
\text { Public Outreach, } \\
\text { Transportation and } \\
\text { Social Solidarity and } \\
\text { Local Democracy. }\end{array}$ & Australia & Quantitative & $\begin{array}{c}\text { 1. Collection } \\
\text { of urban } \\
\text { viability } \\
\text { definitionsA } \\
\text { nd social } \\
\text { characteristi } \\
\text { cs- } \\
\text { combination } \\
\text { of different } \\
\text { indicators of } \\
\text { viability. } 3 \text {. } \\
\text { Evaluative } \\
\text { quality of } \\
\text { viability }\end{array}$ & $\begin{array}{l}\text { Urban } \\
\text { liveability:Emerging } \\
\text { Lesson from Australin } \\
\text { for exploring the } \\
\text { potential for indicators } \\
\text { to measure the social } \\
\text { determinants of } \\
\text { health,Socal Science } \\
\text { and Medicine }\end{array}$ & 2014 & $\begin{array}{c}\text { Badland et } \\
\text { al }\end{array}$ \\
\hline $\begin{array}{l}\text { Providing a model for } \\
\text { urban viability suggests } \\
\text { that habitability is } \\
\text { formed by two systems: } \\
\text { 1) natural systems 2- } \\
\text { artificial or man-made } \\
\text { systems }\end{array}$ & $\begin{array}{c}\text { North } \\
\text { American }\end{array}$ & Quantitative & $\begin{array}{l}\text { Study } \\
\text { literature } \\
\text { and various } \\
\text { opinions } \\
\text { about } \\
\text { viability in } \\
\text { the city }\end{array}$ & $\begin{array}{c}\text { Urban livability across } \\
\text { disciplinaryand } \\
\text { professiona. } \\
\text { boundaries }\end{array}$ & 2016 & Kashef \\
\hline
\end{tabular}

Livability is the Persian translation selected for the English term (Livability), and as a result, the livable city is equivalent to the term (Livability city). Livability literature in Urban Planning and Urban Constructing proposes discussions including the creation of a safe and habitable community for citizens and its required requirements; increasingly, the concept of community empowerment is at the first level of the concept of livability (Rashidi Ebrahim Hessari et al., 2016). Livability as a concept can be very wideranging or limited regarding the context in which it is defined, however, the quality of life in any place lies at the heart of attention of this concept, and includes highly measurable various indicators that usually forms concentration, transportation, security and stability of its main constituents (Perogorodo Madrid, 2007). Livability refers to the urban system that takes into account the mental, social, physical and developmental well-being of its inhabitants, and its key principles are justice, dignity, access, interaction, participation, and empowerment (Song, 2011). Economist Information Unit considers livability as a factor which contributes to high quality of life. The overlap and similarity between the two concepts of livability and quality of life has led them to be used interchangeably. While they differ in terms of the presence of the artificial and natural environmental facilities (viability) and the experience and judgment (good, bad, or indifferent) of users after using them (quality of life). Hence, quality of life is a subjective topic connected with the general and public well-being of individuals, and vitality is an objective condition in which social, economic, physical and environmental requirements are provided for the sake of long-term comfort and well-being of a whole community. Therefore, the two concepts are along each other. In other words, the 
desirable quality of life can be realized only in the light of livability in one place (Isa Lo et al., 2014). In general, the perspectives of livability can be classified as follow.

\section{Doyal and Gough's livability theory (THN)}

Doyal and Gough's human needs theory(2009) is a pursuit to meet a higher level of needs that has a particular advantage. The first advantage is related to the ideological dimension, which emphasizes a strong moral relationship between the needs and the commitment of societies to supply and meet them. The second advantage is theoretically providing a rigorous and documented framework for objective needs that are in the broader range of public value approaches. Theoretical starting point is the perception of general needs that all individuals (people) are interested in providing them. Doyal and Gough claim that everyone has a real interest in avoiding serious harm that deprives them of pursuing a dream of a good life and their inability to participate in social life. According to Dyal and Gough perspective, two groups of general needs are among the fundamental goals.

1. Avoiding serious damage or harm; 2. Social participation ability (Olsberg,2012:65).

Theories of human needs can be utilized in accordance with independent standards to compare different communities with a wide range of social, political and economic systems for human well-being, independent of cultural values in any society. (Fattahi et al.,1391:54).

\section{Livability theory and Maslow's basic needs}

Livability theory was first developed based on Abraham Maslow's (1970) work on human needs. The American well-known Psychologist, Abraham Maslow, introduced the pyramid of human needs. Based on this pyramid, first of all, human beings try to solve their own basic needs and then return to the needs of higher layers. The basic physiological needs of humans include his vital needs such as air, food, water, heat, sleep, health and sexual satisfaction. Above this base, the security layer is located. There is a layer of security above that: the need for shelter, job, law, insurance, health services, discipline and order, morality, physical security, financial security, life planning and future development. The third layer involves the factors of spiritual affection: the need for a friend, peer, wife, love, neighbor, conversation and communication with others, treatment and nursing. The fourth layer includes the factors of respect and appreciation: respect, trust, success, position, victory, championship and even wealth and power, social welfare, wealth, power, success, victory, championship. The highest layer is the layer of self-actualization: individuality, beliefs, lack of discrimination. The three lower layers remove shortages and meet basic needs. This means that meeting the needs of these three layers, although makes people feel satisfied, it does not encourage them to move and progress. For example, when eating water, thirst is resolved, but one does not try to eat more water. The fourth layer and the fifth layer show the need for progress and development. These are requirements that will never be resolved (Isa Lo, 2015, 45).

\section{Method}

An applied method is used and the dominant approach in the present research is of two main types of survey and descriptive-analytic. In the present study, the fore-mentioned two methods have been used. To this end, despite of using the observation and field interview about the texture, library study was used for gathering information. A researcher-made questionnaire was used to collect required data and information. The items were compiled based on Lickert-scale of 5 options. The statistical population in the present study consisted of residents of Zanjan city. To determine the sample size, the Cochran formula was used (Hafeznia, 2014) and for collecting data, simple random sampling was employed. The sample size was 384. So, after validating the questionnaire validity using experts' opinions, Cronbach's alpha method was used to measure the reliability of the questionnaire. The Cronbach's alpha obtained in the present study was .902 indicating the high reliability of the questionnaire. To analyze the collected data using SPSS software, 
independent sample T-test and (spatial independence) autocorrelation (Moran analysis) was used. In the present study, based on previous theories and studies, the following indicators were selected and examined to evaluate livability in Zanjan city. Vitality indicators that are used to monitor livability in a given context and within a specified time period using social, economic, environmental, managerial and physical criteria (Khorasani et al., 2014; 7); the indicators help citizens, policymakers and administrators to show the extent to which society is progressing (Lariss, 2005: 5). These indicators are:

Table 1. studied indicators

\begin{tabular}{|l|r|}
\hline \multicolumn{1}{|c|}{ Index } & Dimensions \\
\hline $\begin{array}{l}\text { General education, recreation and leisure, medical and health care } \\
\text { considerations, in dividual and social security, affiliation and place belonging, } \\
\text { participation and solidarity }\end{array}$ & Societal \\
\hline $\begin{array}{l}\text { Consumer goods, employment and income, housing, facilities and infrastructure, } \\
\text { services, public transportation }\end{array}$ & Economic \\
\hline Pollution, visual quality, green space & environmental \\
\hline
\end{tabular}

Source: Library Findings Writer,1395

\section{Research Ecology}

Zanjan city is among the middle cities of the country and the capital of Zanjan province. The city has a long history; it is among the cities that have undergone various periods of prosperity and decline during urbanization dynamism. Zanjan is bounded to the city of Tarom, Khalkhal and Miyaneh from the north and from the east to Abhar and Tarom, and from the south to Qeydar and Zarin Abad, from the west, to Mahneshan, and Charavimahq counties. Due to its ancient history and civilization, Zanjan city has many historical and religious monuments and has a rich history in this regard (Jahan Gostar Monthly, No. 63).

Zanjan city, despite its ancient history in line with well-known cities, lacks a codified historical background. based on the conducted studies, the antiquity and old age of Zanjan region dates back to late second millennium BC (Qizilbash, 2008: 181). Some of the historians have been identified Zanjan city with the city of Aganzana, which Ptolemy has mentioned it (Parchekani, 2004: 179).

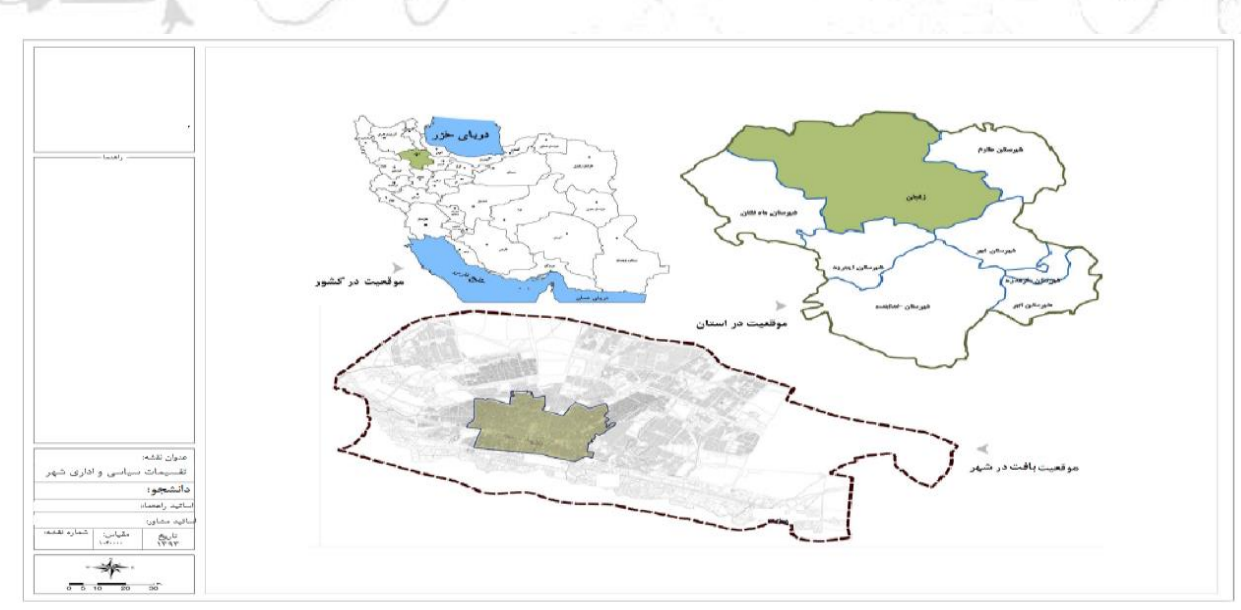

Source:Armansahr, 1388:17

The worn-out texture of Zanjan city is located in the central area of Zanjan city, from the north it leads to the streets of Karegar, Sarbaz and Modarres and 17th Shahrivar, from east to Islamic Republic Street and Keshavarz Boulevard, from west to Motahari avenue and 15 Khordad Boulevard, and from South it leads to Shahid Beheshti Boulevard. This range is based on physical worn-out indicators as defined in the 1384.3.16 pass of the Supreme Council of Urban Development and Architecture of Iran and information provided by 
housing and urban planning organizations and consultants formulating comprehensive and detailed plans and after field control by the parent company of urban construction and improvement (Armanshahr, 2009; Volume I: 3). The project consultant has divided the range into two categories of "historical valued and qualified" and "relatively valued and qualified". This classification is done by considering the values from different dimensions at the level of the worn- out texture of the central part of Zanjan city(ibid).

\section{Data Analysis}

\section{Analysis of livability condition of worn-out texture of Zanjan city with independent sample T-test}

The results of examining the status of livability indices in the worn out tissue of Zanjan city indicate that the mean of urban livability index was 3.18. This value is above average. The value of the $t$ statistic is also with the score of $(t=9.657)$ at the significant level of 0.000 . It can be said that the livability status of wornout texture in Zanjan city is statistically acceptable and desirable. However, a more detailed examination of the liability indicators through a single-sample t-test can reveal a more favorable outcome. To investigate more precisely the livability of the worn-out texture of Zanjan city, using Single Sample T-test, the indices are analyzed separately. At this stage, it can be determined which index or dependent variable is more influenced by the independent variable than the other variables. In other words, which index is more livable. According to the results of presented in Table 2, the social index with the score of $(t=29.655)$ has obtained the highest score. In terms of statistical population, this index is almost identical among the indicators of the livability of the time-out texture of Zanjan city, and the social category in this city is more important and priority and it shows great satisfaction of individuals regarding this situation. This index is related to "leisure and recreation", "partnership and solidarity", "medical and health care", "individual and social security", "place affiliation and belonging," "public education," and so on. After that, the physical index with the score of $(\mathrm{t}=14.768)$ and the economic index with the score of $(\mathrm{t}=6.079)$ are in the next ranks. Finally, the environmental index scoring $(\mathrm{t}=1.078)$ has the lowest score. Thus, according to the statistical population, the degree of livability of the worn-out texture of Zanjan city with a mean of 3.03 is average. And in their view, this amount is not favorable and acceptable in the studied area. Regarding the standard deviation of 0.469 , the discrepancy on statistical population's view in this regard is relatively low, and regarding the significance level of less than $0.05(\mathrm{p}<0.05)$ of the environmental index, the obtained result can be generalized to the whole studied texture.

Table (2) - The status of Zanjan's worn-out habitat indices with a one-sample test

\begin{tabular}{|c|c|c|c|c|c|c|c|c|}
\hline \multicolumn{6}{|c|}{ Test Value $=3$} & \multirow{3}{*}{$\begin{array}{c}\text { Std. } \\
\text { Deviation }\end{array}$} & \multirow{3}{*}{ Mean } & \\
\hline $\begin{array}{r}95 \% \\
\text { Inter } \\
\mathrm{Di}\end{array}$ & $\begin{array}{l}\text { fidence } \\
\text { of the } \\
\text { ence }\end{array}$ & \multirow[t]{2}{*}{$\begin{array}{c}\text { Mean } \\
\text { Difference }\end{array}$} & \multirow{2}{*}{$\begin{array}{l}\text { Sig. } \\
(2- \\
\text { tailed })\end{array}$} & \multirow[t]{2}{*}{ df } & \multirow[t]{2}{*}{$\mathrm{t}$} & & & \\
\hline Upper & Lower & & & & & & & \\
\hline .411 & .360 & .385 & .000 & 380 & 29.655 & .254 & 3.39 & Societal \\
\hline .109 & .056 & .082 & .000 & 380 & 6.079 & .264 & 3.08 & Economic \\
\hline .257 & .197 & .227 & .000 & 380 & 14.768 & .300 & 3.23 & Somatic \\
\hline .073 & -.021 & .026 & .282 & 380 & 1.078 & .469 & 3.03 & Eco-environmental \\
\hline .352 & .290 & .321 & .000 & 380 & 9.657 & 0.429 & 3.18 & All \\
\hline
\end{tabular}

(Source: Findings by the author 91395 )

\section{Spatial independence pattern analysis of livability indicators of worn-out texture in Zanjan city}

General spatial independence pattern analysis (autocorrelation) can be used to describe the spatial characteristics of a variable in the whole district and the mean of spatial difference between all spatial 
cells and their adjacent cells can be determined (Goodchild, 1986: 35). In fact, this indicator measures spatial difference of livability values between each cell (texture) and its adjacent cells (neighborhoods) and evaluates its significance (Anselin, 1995: 101). ). The results of the local Moran statistics can be tested by Z scores. A confidence level is determined, if the cell i (city) has a positive significance (i.e., a positive number), the value of the statistics (livability coefficient) of the cell $\mathrm{i}$ will be similar to that of the adjacent cells. If the Ii value is a positive large number, it indicates a strong clustering limit. On the other hand, if Ii value is negative and significant, the surface temperature of the cell i differs greatly from its adjacent cells, indicating a negative spatial correlation (Dai et al, 2010: 249). In general, in spatial pattern classification of either cluster or random and dispersed, one can focus on the ordering and arrangement of regional units. The similarity and dissimilarity of each pair of adjacent region units can be measured. When the similarity and dissimilarity are summed up for spatial patterns, spatial independence (autocorrelation) is formed (Lee, 2000: 135). Spatial independence (autocorrelation) is a valuable instrument for studying how spatial patterns change over time.

\section{Spatial independence Analysis of Social index of worn-out texture in Zanjan city}

According to the findings of illustrated in Table 3, social livability data of Zanjan's worn out texture at all levels of spatial resolution have positive spatial self-correlation. Comparison of values obtained with significant threshold showed that all values obtained for all years is significant at significant level of $\alpha=0.05$. Therefore, based on the results the lack of spatial relationship of social structure in the worn-out texture of Zanjan city is rejected and the existence of social spatial dependence is confirmed. According to the Moran index, the distribution of autocorrelation of the social index is dispersed, and the distribution with negative and near-zero coefficients is unconventional and unbalanced. Since the value nearer to 1 indicates a higher concentration. This result suggests that the social index is not decentralized at the level of the texture. Thus, Debaghlar neighborhoods with a coefficient of $(Z$ score $=1.631459)$ are at the highest rank. Following that, Mashhadi Safar neighborhood with coefficient of $(Z$ score $=1.053169)$, and Agharahim with coefficient of $(\mathrm{Z}$ score $=1.017779)$ are placed in the next ranks. Thus, the abovementioned neighborhoods have the most similarity and likeness, and in general, spatial (autocorrelation) in the social indicators to each other. In contrast, Ghahraman neighborhoods with a coefficient of ( Z Score $=2.182889)$ are ranked in the lowest rank. Subsequently, Degarman orkhi neighborhoods with coefficients of $(\mathrm{Z}$ score $=1.961682)$, and Shoghii with a coefficient of $(\mathrm{Z}$ score $=1.185559)$ are in the next ranks. As a result, the three neighborhoods, especially the Ghahraman neighborhood, have the least similarity and spatial dependence on social indicators in the context of other areas.

\section{Spatial autocorrelation analysis of economic index of the worn-out texture of Zanjan city}

According to the Moran index, the spatial correlation distribution of the economic index is dispersed, and the distribution with negative and near zero coefficients is unbalanced and unconventional. Comparison of this situation with Moran coefficient of economic livability index, it can be said that to some extent the unfair distribution situation is relatively observed.

In this regard, Yukari Cemetery with a coefficient of $(Z$ score $=2.10255)$ is in the highest rank. Subsequently, Debaghlar neighborhoods with a coefficient of $(Z$ score $=1.79041)$, and Haghverdi neighborhoods with a coefficient of $(Z$ Score $=1.67874)$ are in the next ranks. Thus, the above-mentioned neighborhoods are the most similar and identical ones, and in general, have independency in economic indicators to each other.

In contrast, Degarman orkhi neighborhood with a coefficient of $(Z$ Score $=2.63309)$ is in the lowest rank, followed by Shoghi neighborhood with the coefficient of $(Z$ Score=1.07289), and Seidler with a coefficient of $(Z$ Score $=0.666567)$. As a result, the three neighborhoods, in particular the Seidler neighborhood, have the least similarity and spatial dependence on economic indicators in the context compared to other neighborhoods. 


\section{Spatial independence analysis of body indicator worn- out texture in Zanjan city}

Based on Moran index, the spatial autocorrelation distribution of the physical index is dispersed, and the distribution with negative and near zero coefficient is unbalanced and unconventional. Comparison of this situation with Moran coefficient of physical livability index, it can be said that to some extent the unfair distribution situation is relatively observed. In this regard, the Debaghlar neighborhood has the highest rank with a coefficient of $(\mathrm{Z}$ score $=1.512979)$ followed by Yeriballa neighborhood with a coefficient of $(\mathrm{Z}$ score $=1.30153)$, and Yeripaein with a coefficient of $(Z$ score $=1.27056)$. Hence, the above-mentioned neighborhoods have the most similarity and the resemblance, and in general, spatial independence (autocorrelation) exists in physical indices. In contrast, the Degarman Orkhi, with a coefficient of Z Score $=2.44654$ are in the lowest rank followed by Shoghi neighborhoods with coefficients of (Z Score $=1.89181$ ), and Mashhadi Safar with coefficient of ( $Z$ Score $=1.447939)$. As a result, the three neighborhoods, in particular, Degarman Orkhi neighborhood, have the smallest similarity and spatial dependency in the physical indices in the texture compared to other neighborhoods.

\section{Spatial autocorrelation analysis of environmental index of the worn-out texture of Zanjan city}

In the context of environmental issues, the worn-out texture of Zanjan city has many problems. Of course, the environmental conditions of Darvazeh Ark, Hosseinyeh and Airport are relatively favorable (Map 2). In addition, according to the findings presented in Table 3, based on Moran index, the distribution of spatial autocorrelation of the environmental index is dispersed and the amount of distribution with a negative and near zero coefficients is unconventional and unbalanced. By comparing this with the Moran coefficient of the environmental livability index, it can be said that to some extent the unfair distribution situation is relatively observable. Therefore, Davoudqoli neighborhood with a coefficient of $(Z$ score $=0.805615)$ is in the highest rank followed by Amjadiyeh neighborhood with coefficient of $(Z$ score $=0.778428)$ and North Sa'di with a coefficient of $(Z$ score $=0.778428)$. Thus, the above-mentioned neighborhoods are the most similar and identical, and in general, have spatial autocorrelation is one of the environmental indicators. In contrast, Hosseiniyeh with a coefficient of $(Z$ score $=1.99239)$ is ranked in the lowest rank followed by Biseim with the coefficient of $(\mathrm{Z}$ score $=1.785789)$ and Homayoun with the coefficient of $(\mathrm{Z}$ score $=$ 1.41785). As a result, these three neighborhoods, especially Hosseiniyeh, have the least similarity and spatial dependency in the environmental indicators in the texture than other districts.

\section{Spatial autocorrelation analysis of the livability of the worn-out texture}

Considering the findings illustrated in Table 3, and based on Moran index, the spatial autocorrelation distribution of livability index is dispersed, and the distribution value with a negative and near zero coefficients are unconventional and unbalanced. As the value tends towards number 1 , it indicates a higher concentration. This result suggests the lack of unbalanced concentration at the texture level.

This situation is illustrated in map 2. Comparison of this situation with the Moran coefficient of livability index, it can be said that to some extent the unbalanced distribution situation is relatively observed. In this regard, it can be said that the Debaghlar neighborhood has the highest rank with a coefficient of $(\mathrm{Z}$ score= 1.578629) followed by Yeriballa neighborhood with a coefficient of $(Z$ score $=1.41092)$ and Haghverdi neighborhood with a coefficient of $(\mathrm{Z}$ score $=1.301319)$.

Thus, the above-mentioned neighborhoods have the most similarity and resemblance, and in general, they have the spatial autocorrelation in the livability indices. Conversely, the neighborhoods of Degerman Orkhi with a coefficient of $(Z$ score $=2.715929)$ are ranked at the lowest rank followed by Shoqi neighborhood with coefficient of $(Z$ score $=1.503839)$, and Darvazeh Ark with a coefficient of $(Z$ score $=0.779609)$. As a result, the three neighborhoods, especially Degerman Orkhi, have the least similarity and spatial dependence on the livability indices in the texture compared to other neighborhoods. 
Map (2) - Spatial correlation pattern of endangered tissue elasticity indexes in Zanjan city with Moran statistic coefficient

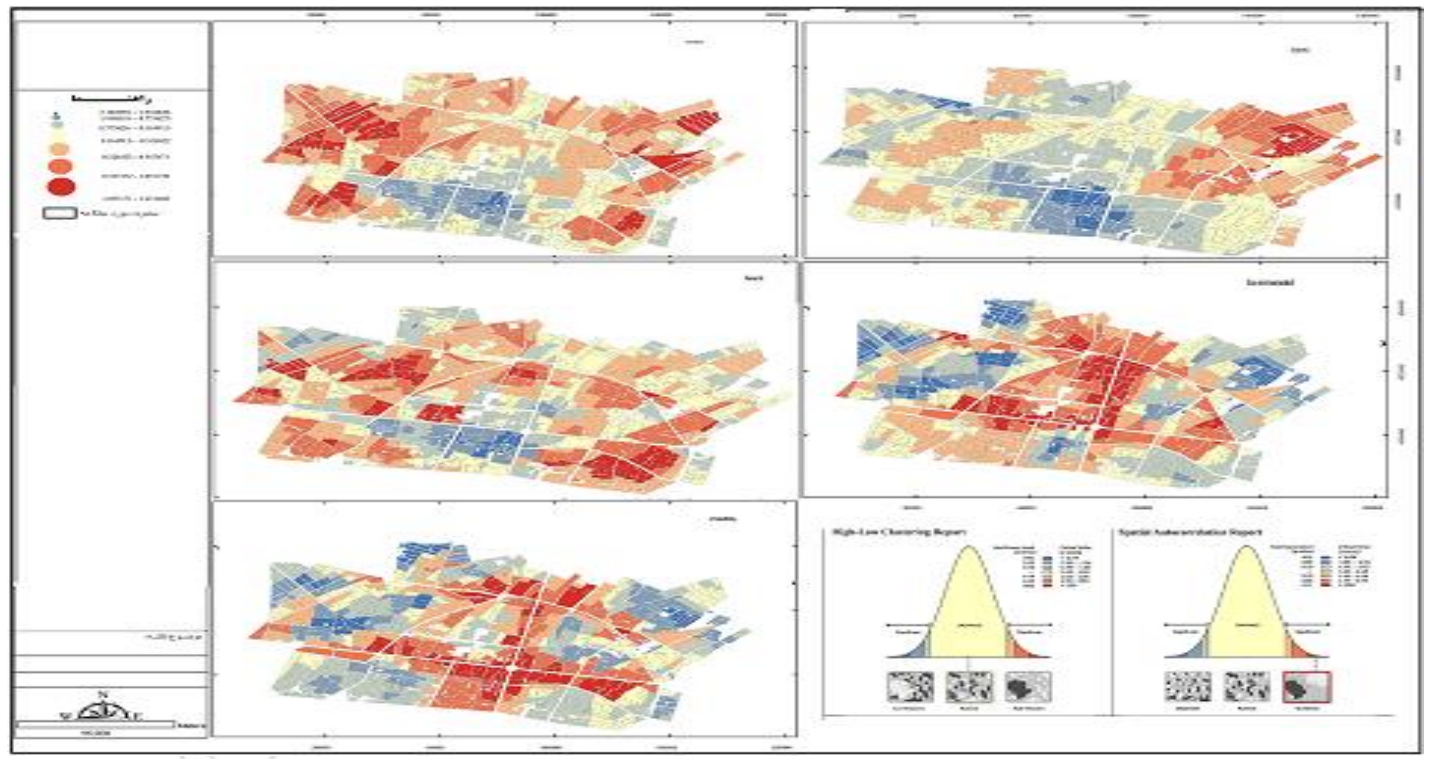

Table (3): Self-correlation pattern of Zanjan city's morbidity indices with Moran statistic coefficient

\begin{tabular}{|c|c|c|c|c|c|c|c|c|c|c|}
\hline \multicolumn{2}{|c|}{ Total } & \multicolumn{2}{|c|}{ environmental } & \multicolumn{2}{|c|}{ Physical } & \multicolumn{2}{|c|}{ Economic } & \multicolumn{2}{|c|}{ Isocial } & \\
\hline \begin{tabular}{l}
5 \\
\multirow{2}{3}{} \\
0 \\
0 \\
0 \\
0
\end{tabular} & 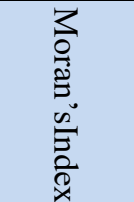 & 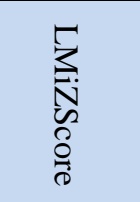 & 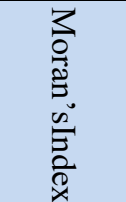 & 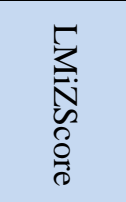 & 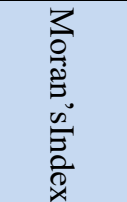 & 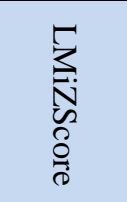 & 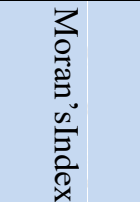 & 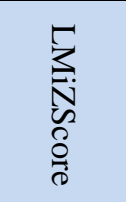 & 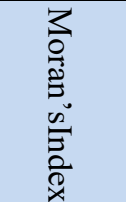 & \\
\hline-1.503839 & -0.000136 & 0.329479 & 0.000022 & -1.89181 & -0.000171 & -1.07289 & -0.000098 & -1.185559 & -0.000108 & Shoghi \\
\hline 0.692324 & 0.00004 & 0.778428 & 0.000045 & 0.621295 & 0.000036 & -0.407272 & -0.000027 & 0.390163 & 0.000021 & North saadi \\
\hline 0.332821 & 0.000049 & -1.41785 & -0.000342 & 0.116438 & 0.000001 & 0.483707 & 0.000081 & 0.493113 & 0.000084 & Homayoun \\
\hline 0.692324 & 0.00004 & 0.778428 & 0.000045 & 0.621295 & 0.000036 & -0.407272 & -0.000027 & 0.390163 & 0.000021 & Amjadiyeh \\
\hline-0.266575 & -0.00005 & -1.785789 & -0.00028 & -0.158195 & -0.000034 & 1.336789 & 0.000188 & & 0.000051 & \\
\hline-0.41833 & -0.00011 & 448406 & 0.000088 & -0.484447 & -0.000125 & 0.437862 & 0.000084 & -0.381054 & -0.0001 & darwazi Rasht \\
\hline 0.122853 & 0.000013 & 0.469785 & 0.000086 & -0.073582 & -0.000028 & 1.09237 & 0.000214 & 0.186311 & 0.000026 & Garibia \\
\hline-0.043143 & -0.000004 & 0.805615 & 0.000037 & -0.038061 & -0.000003 & -0.200172 & -0.000011 & 0.324822 & 0.000013 & David Gholi \\
\hline-0.363608 & -0.00003 & 0.724779 & 0.000048 & -0.168063 & -0.000016 & 0.711247 & 0.000046 & -2.182889 & -0.00016 & Gahraman \\
\hline 0.839089 & 0.000069 & 0.20761 & 0.000013 & 0.901495 & 00075 & 2.10255 & 0.00018 & -0.773626 & -0.000073 & Mazarbala \\
\hline 1.578629 & 0.000248 & 0.172447 & & 1.512979 & & 1.79041 & 0.000279 & 1.631459 & 0.000254 & Dabbaglar \\
\hline 1.17127 & 0.000423 & 447463 & & 1.27056 & & 0.926972 & 0.000324 & 0.703244 & 0.000239 & \\
\hline 1.41092 & 0.0005 & 0.481382 & 0.000153 & 1.30153 & 0.000462 & 1.180469 & 0.000408 & 0.957705 & 0.000327 & Yeri Balla \\
\hline 1.053609 & & & & & & & & 1.017779 & 0.000247 & Agha Rahim \\
\hline-0.517211 & -0.000135 & -0.962481 & -0.00023 & -1.447939 & -0.000335 & 1.002799 & 0.000187 & 1.053169 & 0.000198 & Mashdi Safar \\
\hline 0.209023 & 0.000055 & 0.17041 & 0.000433 & 0.397543 & & -0.307725 & & 0.103215 & & Abbasgoli \\
\hline 0.204125 & 0.000052 & 0.14124 & 0.000416 & 0.37994 & 0.000121 & 0.07934 & 0.000004 & -0.164912 & -0.000088 & Sarchesmeh \\
\hline-0.779609 & -0.000191 & -0.166978 & & -1.081719 & & & -0.000096 & 0.289245 & 0.000046 & Darvazeh Ark \\
\hline 0.273185 & 0.000013 & 0.731294 & 0.00004 & 1.073459 & 0.000059 & -0.666567 & -0.00004 & -0.841159 & -0.00005 & Seyedlar \\
\hline 0.542541 & 0.000069 & 0.020406 & -0.00001 & 0.698647 & 0.000093 & 0.519029 & 0.000064 & 0.54747 & 0.000069 & Mehdikhan \\
\hline 0.739615 & 0.000156 & 0.123853 & 0.000008 & 0.207053 & 0.000028 & 0.998897 & 0.000216 & 0.77307 & 0.000163 & Nasrollakhan \\
\hline-2.715929 & -0.000766 & -0.631599 & -0.000199 & -2.44654 & -0.000695 & -2.63309 & -0.000735 & -1.91682 & -0.000544 & Degarman Orkhi \\
\hline 1.301319 & 0.000334 & 0.185507 & 0.000024 & -0.431665 & -0.000148 & 1.67874 & 0.000433 & 0.840596 & 0.000204 & Hagverdi \\
\hline 0.876348 & 0.000225 & 0.32012 & 0.000066 & 0.582746 & & 1.17707 & & 0.464704 & 0.000106 & \\
\hline 0.053336 & -0.000013 & -1.99239 & -0.000652 & 0.623529 & 0.000164 & 0.476379 & 0.000116 & 0.263271 & 0.000051 & Zeinabieh \\
\hline 0.894802 & 0.000141 & 0.20964 & 0.000197 & 0.367283 & 0.000049 & 0.815075 & 0.000125 & -0.458701 & -0.000095 & Fordghah \\
\hline
\end{tabular}




\section{Conclusion and Discussion}

Investigating the livability of cities, according to the WSDOT theory, it is a viable future, a potent, dynamic, and accountable urban society and offers a desirable quality of life. It depends on the three keys of the goals of society, namely, dynamism, and a thriving economy and a sustainable environment. In this regard, one of the ways to recognize the impact of a phenomenon and element on the system is to determine the amount of its power and capabilities. In urban planning era, cities have a strong impact on urban space, which have better internal condition in terms of quality of life and social, economic, political, physical and environmental structures. Under such conditions, cities will have the ability to attract capital, resources, population and creating a strong and dominant relationship with other cities and settlements. Considering the fact that that the theory of an ideal city is based on the optimistic conception of the possibility of creating cities that are systematic in any way and under the strict supervision of the state or religious, political or legal organizations, or managed by philosophers, intellectuals, or ideologists. In cities of Iran, the same is true; it means that cities with more favorable conditions in terms of livability conditions have a greater impact on the economic, social, political, environmental and urban spatial structures. In the investigation of the livability of the worn-out texture of Zanjan city, it was shown that the social index with score of $(t=29.655)$ obtained the highest score among the indicators of livability. Statistically, this index is almost identical among the indicators of the livability of the worn-out texture of Zanjan city. In addition, the social category in this city is a priority and people are more satisfied with this situation. This index is related to "leisure and recreation", "partnership and solidarity", "medical and health care", "individual and social security", "place affiliation and belonging," "public education," and so on. After that, the physical index with the score of $(\mathrm{t}=14.768)$, and the economic index with the score of $(\mathrm{t}=6.079)$ are in the next ranks. Finally, the environmental index with the score of $(t=1.078)$ obtained the lowest score and, in their view, this amount is not desirable and acceptable in the studied area.

According to social-livability indices, Debaghlar neighborhoods with the coefficient of $(Z$ score $=1.631459)$ are in the highest rank followed by Mashhadi Safar neighborhood with coefficient of ( $Z$ score $=1.053169)$, and Agharahem neighborhood with coefficient of $(Z$ score=1.017779). Thus, the above-mentioned neighborhoods are the most similarity and resemblance, and in general, spatial independency, among social indicators towards each other. considering Moran coefficient of economic livability index it can be said that to some extent the situation of relatively unfair distribution is observed. So, Yukari cemetery with the coefficient of $(Z$ score $=2.10255)$ is in the highest rank. Subsequently, Debaghlar neighborhoods with a coefficient of $(Z$ score $=1.79041)$, Haghverdi neighborhood $(Z$ score $=1.67874)$ are placed in the next rank. Autocorrelation analysis of the physical index of the worn-out texture of Zanjan city showed that the Debaghlar neighborhood has the highest rank with the coefficient of $(Z$ score $=1.512979)$ followed by Yeriballa neighborhood with coefficient of $(\mathrm{Z}$ score $=1.30153)$, and Yeripaein neighborhood with coefficient of $(\mathrm{Z}$ score $=1.27056)$. Thus, the above-mentioned neighborhoods have the most similarity and resemblance to each other, and in general, autocorrelation in physical indices. In addition, the analysis of the environmental (livability) index in the worn -out texture of Zanjan revealed that the Debaghllar neighborhood with the coefficient of $(Z$ score $=1.578629)$ is in the highest rank followed by Yeriballa neighborhood by the coefficient of $(Z$ score $=1.41092)$, and Haghverdi neighborhood ( $Z$ score $=1.301319)$. Consequently, the above-mentioned neighborhoods have the most similarity and the resemblance to each other, and in general, they have spatial autocorrelation in the indices of livability.

\section{References}

Bandar Abad; Alireza (2011), livable City; Urbanization searches; Summer and Autumn; No. 36

Bandar Abad, Alireza (2014), Evaluation of Quality of Life Indicators with Emphasis on the Principles of livable City, Journal of Urban Planning Research, 5(16), Spring.

Parchekani, Hamideh (2007); Physical Development of Zanjan City, Master's Thesis, Zanjan University 
Jome'pour, Mahmoud, Tahmasbi, Shahrzad (2013); formulating the degree of livability and Quality of Life in Villages around city, Quarterly Journal of Physical-spatial Planning, First Year, No. 3.

Habibi, et al., Kiyoumars (2008), From Zangan to Zanjan (survey on the physical-spatial transformations of the old texture of the city) Zanjan University Press

Heidari, Taqi (2016). Analysis of the livability of worn-out urban texture: Case Study: Worn-out extures in the Central District of Zanjan city, Doctorate dissertation at Kharazmi University of Tehran

Habibi, Davoud, Ghashghaii, Reza, Heydari, Farzad (2013); A look at the characteristics and criteria of the livable city, International Conference on Civil Engineering, Architecture and Sustainable Urban Development, Tehran.

Hafeznia, Mohammad Reza, (2014); Introduction to Research Method in Humanities, 20th Edition, Samt publications, Tehran.

Korasani et al. Mohamad Amin(2013),Measurement and evaluation of livability components in settlements in the country(Case study: Varamin County); Rural Development, Vol. 5, No. 1, Spring and Summer

Rashidi Ebrahim Hesari, Asghar, Movahed, Ali, Tullayi, Simin, Mousavi, Mir Najaf (2016); Spatial Analysis of Tabriz Metropolitan Area with livability Approach, Journal of Geography, Ahar University of Medical Sciences, 54(16), 176-155.

Sasanpour et al, Farzaneh (2014), livability of cities in line with sustainable development (Case study: Tehran metropolis), Journal of the Iranian Geographic Society, New Year, Autumn, No 42, Autumn.

Saifoddini, Frank (2002); The fundamentals of Urban Planning, Aijiz Publication, Tehran

Isa Lo, Ali Asghar \& et al. (2015); Indicators of livability in Urban Environment (Case Study: Central Section of Holy City of Qom), Journal of Urban Economics and Management, Vol. 4, No. 13, 110118.

Qezelbash, Somayeh (2008), Physical livability in the informal settlements of cities and their effect on the occurrence of social anomalies: case study: Informal settlement Area in Zanjan; Master's Thesis, Zanjan University.

Kaviani Rad, Morad, Fattahi, Mostafa (2012); The Impact of Spatial Identity on National Convergence, Quarterly Journal of Planning and Space Design, Vol. 16, No. 1

Motavasseli, Behnam (2012); Study of the Effects of Industrial Towns in Sustainable Urban Development (Case Study: Mehriz City), Master's Thesis for Geography and Urban Planning, University of Gastan

Majedi et al., Hamid (2014); Review of the global and indigenous standards of the livable city, the publication of the identity of the city, the seventh issue, the eighth year, spring. 18. Armanshahr Consultant Engineers (2009), Current status studies of worn-out texture in Zanjan city; Road and Urban Development Office of Zanjan Province.

Song yang (2011), a livable city study in china: using structural Equation models, thesis submitted in statistics, department of statistics Uppsala university

Larice, M,Z (2005) "great neighborhoods: the livability and morphology high density neighborhoods in urban north America”, PHD

Pacione,M.,(1990).urban liveability: a review.urbban Geogr.11,1-30.

Perogordo ,M.,p, (2007) “The silesia Megapolis, European Spatial planning “,.

Miller, c., Mac alister J, (2013), Vitality in urban space,livalble city corerence, sidny,Auostralia.

Olajuyibe,A.E., osakpolor ,S.\& A degboyeaga, S.A(.2013). System Approach for Assessment of Life Using Geographical Information Poverty Allviation Decision -Making interational Journal of Sustainable Land Use and urban planing, Vol.1,No.1,1-25.

Badland,Hannah. Whitzman,Lowe, Aye,Butterwoth,Hes 2014. Urban liveability:Emerging Lesson from Australin for exploring the potential for indicators to measure the social determinants of health,Socal Science and Medicine, No111,pp64-73.

Mohamad.Kashef.,(2016). Urban livability across disciplinaryand professional boundaries. Abu Dhabi 38772, United Arab Emirates, www.elsevier.com/locate/foar. 